NOT FOR QUOTATION

WITHOUT PERMISSION

OF THE AUTHOR

\begin{abstract}
INNOVATIVE ADAPTATION THROUGH THE:
QUAST-TREE: STRUCTURE: AN FMERGING

ASPECT DF JAPANESE ENTREPRENEURSHIP
\end{abstract}

Masahiko Aoki

September 1983

CP-B3-40

Collaborative Papers report work which has not been performed solely at the International Institute for Applied Systems Analysis and which has received only limited review. Views or opinions expressed herein do not necessarily represent those of the Institute, its National Member Organizations, or other organizations supporting the work.

INTERNATIONAL INSTITUTE FOR APPLIED SYSTEMS ANALYSIS

2361 Laxenburg, Austria 


\section{FOREWORD}

This Collaborative Paper is one of a series embodying the outcome of a workshop and conference on Economic Structural Change: Analytical Issues, held at IIASA in July and August of 1983. The conference and workshop formed part of the continuing IIASA program on Patterns of Economic Structural Change and Industrial Adjustment.

Structural change was interpreted very broadly: the topics covered included the nature and causes of changes in different sectors of the world economy, the relationship between international markets and national economies, and issues of organization and incentives in large economic systems.

There is a general consensus that important economic structural changes are occurring in the world economy. There are, however, several alternative approaches to measuring these changes, to modeling the process, and to devising appropriate responses in terms of policy measures and institutional redesign. Other interesting questions concern the role of the international economic system in transmitting such changes, and the merits of alternative modes of economic organization in responding to structural change. All of these issues were addressed by participants in the workshop and conference. and will be the focus of the continuation of the research program's work.

Geoffrey Heal Anatoli Smyshlyaev Ernö Zalai 


\title{
INNOVATTVE ADAPTATION THROUGH THE QUASI-TREE STRUCTURE: AN EMERGING ASPECT OF JAPANESE ENTREPRENEURSHP
}

\author{
Masahiko Aoki*
}

\section{INTRODUCTION}

This paper describes an emerging aspect of Japanese industrial organization and inquires into the nature of the entrepreneurship operating therein. Posing the problem in this way immediately raises one fundamental question. That is, are there any temporal or national variations in the pattern of entrepreneurial behavior in modern firms? My own answer to this question, as presented here, is simply in the affirmative. I will submit that, from the beginning of the 1970s onward, the most important function of the entrepreneur has become that of adapting the internal structure and external behavior of firms quickly, flexibly, and innovatively to increasing environmental uncertainties caused by such factors as supply shocks, the new opportunities that have opened up for technological innovation, the absolute as well as relative variability of prices, interest rates, and exchange rates, etc. I will further argue that Japanese firms have responded to this task by developing a rather new form of industrial organization, which I will term the "quasi-tree structure."

\section{THE SCHUMPETERIAN VIEW OF THE ENTREPRENEUR}

In the beginning there was the (neo)classical notion of entrepreneurship the unification of risk-bearing and control of production -- and many theoreticians still talk about entrepreneurship in these terms. In spite of the apparent separation of the two functions in modern firms between risk-taking shareholders and controlling managers, this (neo)classical concept has been vigorously defended (for example, by Frank Knight) on the basis that this separation is deceptive because ultimate control is still in the hands of shareholders who select managers who exercise only relatively routine control over business

"Institute of Economics, Kyoto University. Kyoto 606, Japan. 
affairs. The relevance and accuracy of this view seems, however, to be eroding in the eyes of many observers. Indeed, portfolio theory tells us that the optimal portfolio for any one investor is likely to be diversified across the shares of many firms. Since he holds shares in many firms precisely to avoid having his wealth depend too much upon any single firm, an individual shareholder generally has neither any special interest in, nor power to, personally control a specific management effectively.

Joseph Schumpeter then proposed an attractive concept of entrepreneurship. which seemed to cope with this situation better. In short, he identified entrepreneurship with the "mechanism of change"1 and the entrepreneur with the bearer of this mechanism. Anyone who actually fulfills this function is an entrepreneur; the employed managers can be entrepreneurs, while shareholders per se are not, although individual shareholders may be. This much seems to be all right, but Schumpeter's position came to be identified more with his later, less universal, claim that entrepreneurship is closely associated with "bigness". He argued that in innovative efforts there are increasing returns both to the size of innovative activities (R\&D establishment) and to the size of the firm. Further, innovation requires a relatively sizeable commitment of resources and commensurate returns to make it worthwhile. Thus only a firm that can attain at least temporary monopoly power will find innovation either attractive or possible. Various empirical evidence contrary to this claim has been accumulated (see for example Scherer 1967, Kamien and Schwartz 1975) but, in order to develop my own views on entrepreneurship. I dare to reiterate here the arguments as to why large size $p e r$ se is not conducive to innovation. particularly in the newly developing industrial situation in the 1970s and 1980s.

\section{ADAPTABIITY AND SIZE}

In the 1950s and 1960s, Japanese and West European firms were very much obsessed with their small size relative to their American rivals and, in the face of increasing international competition for domestic markets, strove for larger size through internal growth as well as mergers. The main emphasis then was on cost reduction through the exploitation of economies of scale and scope, financial viability, large-scale R\&D establishments, etc. But, as Burton Klein has recently emphatically argued (Klein 1979), there are serious questions as to whether such physical bases for short-run cost reduction are compatible with market openness of managerial ability to quickly feed back market information into the development of truly technologically innovative products. The incompatibility of bureaucracy with inventiveness may also manifest itself because of long lines of communications and resulting inefficient utilization of knowledge dispersal within the firm. As Frederick Hayek (1945) argued convincingly some time ago in the context of the market planning vs. central planning issue, economically useful knowledge is never confined to research labs. As the relative success of the recent "quality control movement" at Japanese factories may indicate, collectively accumulated knowledge on the shop floor and other levels can lead to piecemeal improvements and innovations concerning productive processes, the aggregate result of which may very well be nonnegligible. But bureaucracies tend to be insensitive to internal voices from below.

One of the organizational innovations designed to cope with bureaucratic inefficiency in large-sized firms was the introduction of the multidivisional firm. But, ironically, this organizational form has itself created another problem. In order to control and manage multiple divisions engaged in diverse activities effectively, financial specialists who operate in the common 
denominator of dollars have become increasingly influential and dominant in the top management of multidivisional firms, while the importance of other managers specialized in marketing, engineering, and personnel policy has tended to decline to a secondary position. The financial specialists are trained and thoroughly attuned to strive for the incessant pursuit of share-price maximization. However, as the recent theoretical literature on shareholder unanimity suggests, share-price maximization may not be an efficient collective objective even from the shareholders' point of view, if there is firm-specific risk involved in investment and if the shareholders disagree in risk assessment and attitudes toward risk.

Further, myopic share-price maximization may lead to another type of internal inefficiency, if it is combined with inflexible wage adjustments. As the firm-specific employment structure emerges, the bargaining "game" between the manager (as an agent of the shareholders) and the employees ceases to be of the zero-sum type and becomes one of the integrative type, to use Raiffa's terminology (Raiffa 1982). That is, in certain circumstances it is possible to increase the size of the "pie" to mutual advantage by trading between the current wage level and other benefits accruing to employees (better job security or chances of promotion, etc.) made possible through the growth of the firm. But, as I suggested elsewhere (Aoki 1982), if the management strives to adjust managerial policies, for example, on employment and investment, so as to maximize the share-price in changing environments, while wage levels are fixed for a relatively long period, the firm tends to choose Pareto-inefficient outcomes from the viewpoint of existing employees and current shareholders. The chosen policies tend to curtail nonwage benefits accruing to the employees; and the employees are likely to retaliate by demanding higher wages at the next round of management-union negotiations. A higher wage level would, in turn, restrict the adaptability of the management to the external environment. This is clearly a "prisoners' dilemma" situation. What is to blame here is not share-price maximization per se, but myopic share-price maximization combined with inflexible wage adjustments. Managers' innovative adaptability is also limited by the inflexibility of human resource management in general, extending to rigid job specifications and restrictions on interjob transfers, which are nothing but a disguised form of control over employment by the unions.

In summary, exclusive emphasis on the physical basis of technological achievement, bureaucratic stifling of internal communication, myopic shareprice maximization, and inflexible human resource management seem to have severely limited the adaptability of large organizations to changes in the corporate environment. But during the period of relatively stable growth in the 1960s, this increasing lack of adaptability did not appear to outweigh to any significant degree those benefits accruing from "bigness".

In the 1970s, however, the environment changed drastically. The sudden large rise in raw material prices and the sharp slow-down in total factor productivity growth plagued most industrialized economies. Various newly industrialized countries successfully penetrated into the traditional domains of Western industries. The new prospect for technological innovation cast doubt on the wisdom of exclusive emphasis on short-run cost-benefit thinking, whilst favoring ventures involving the future transformation of initially costly innovative products into well-accepted consumer commodities. A series of changes or reversals in government spending policies, high and volatile rates of inflation, and greater instability of foreign exchange and interest rates have contributed additional uncertainty to the corporate economic environment. 
The entreprenurial function under such circumstances has been very neatly summarized by Paul Geroski and Alexis Jacquemin (1983, pp.7.8) as follows:

\begin{abstract}
"Important supply shocks require the ability to adapt to a new environment, to create and rapidly implement new techniques or methods of operation, to shift resources into new fields and away from traditional areas of activity. It is less a question of minimizing costs given known techniques and fairly stable factor prices and product demands as one of finding and developing new techniques and products appropriate for very different factor price constellations and shifting grounds of comparative advantage. Indeed in such cases, the need for flexible and reasonably rapid adjustment to new circumstances is liable to require some sacrifice of static efficiency and the need to do new things fairly rapidly impedes the intensive study and perfection needed to do them well."
\end{abstract}

The problem facing us now is: what mechanism can be conducive to such flexible, quick, and innovative adaptation without sacrificing some of the advantages associated with "bigness" such as the availability of internal funds, the avoidance of costly duplication of inventive activities, risk spreading through diversification, etc.?

\title{
4. QUASI-DISINTEGRATION OF' FIRMS
}

One of the recent measures widely adopted by large Japanese firms to enhance their flexible adaptability while retaining advantages of scale already achieved is the extensive development of subsidiaries and subcontracting. We will begin with a discussion of subsidiaries.

The quasi-disintegration tendency involved in the setting up of subsidiaries is remarkably different from the parallel departure of engineers and managers from large established firms in the United States, in that the initiative in Japan lies with the existing firms. Subsidiaries are created by large Japanese firms by hiving off their own managers and letting them organize hitherto internalized functions or completely new activities from scratch in the form of new firms, more often than by acquiring existing firms.

Table 1 summarizes the extent of this hiving off in terms of the extent to which subsidiaries have been set up over the period 1966-19B2 by the firms listed on the Tokyo Stock Exchange, across all industries, in three selected industries, and in two leading firms in the electric machinery and electronics industry. Matsushita Electric Machinery Corporation and Hitachi Manufacturing Corporation are, respectively, the first and second largest firms in that industry in terms of sales. $H V F 1$ is the ratio of (aggregated) investment by the firm(s) concerned in its (their) subsidiaries to the value of its (their) own paidin capital. Subsidiaries are defined as those firms for which $50 \%$ or more of the stock is owned by parent firms. HVFZ denotes the ratio of (aggregated) investments by the firm(s) concerned in its (their) "related firms" (kankei-kaisha) to the value of its (their) own paid-in capital. Related firms are defined as those firms for which $20 \%$ or more of the stock is owned by the firm itself and its own parent firm, if such exists. Since reciprocal shareholdings by subsidiaries in their parent firms' stock were permissible until recently (and reciprocal shareholdings by nonsubsidiary but related firms are still permitted and practiced 


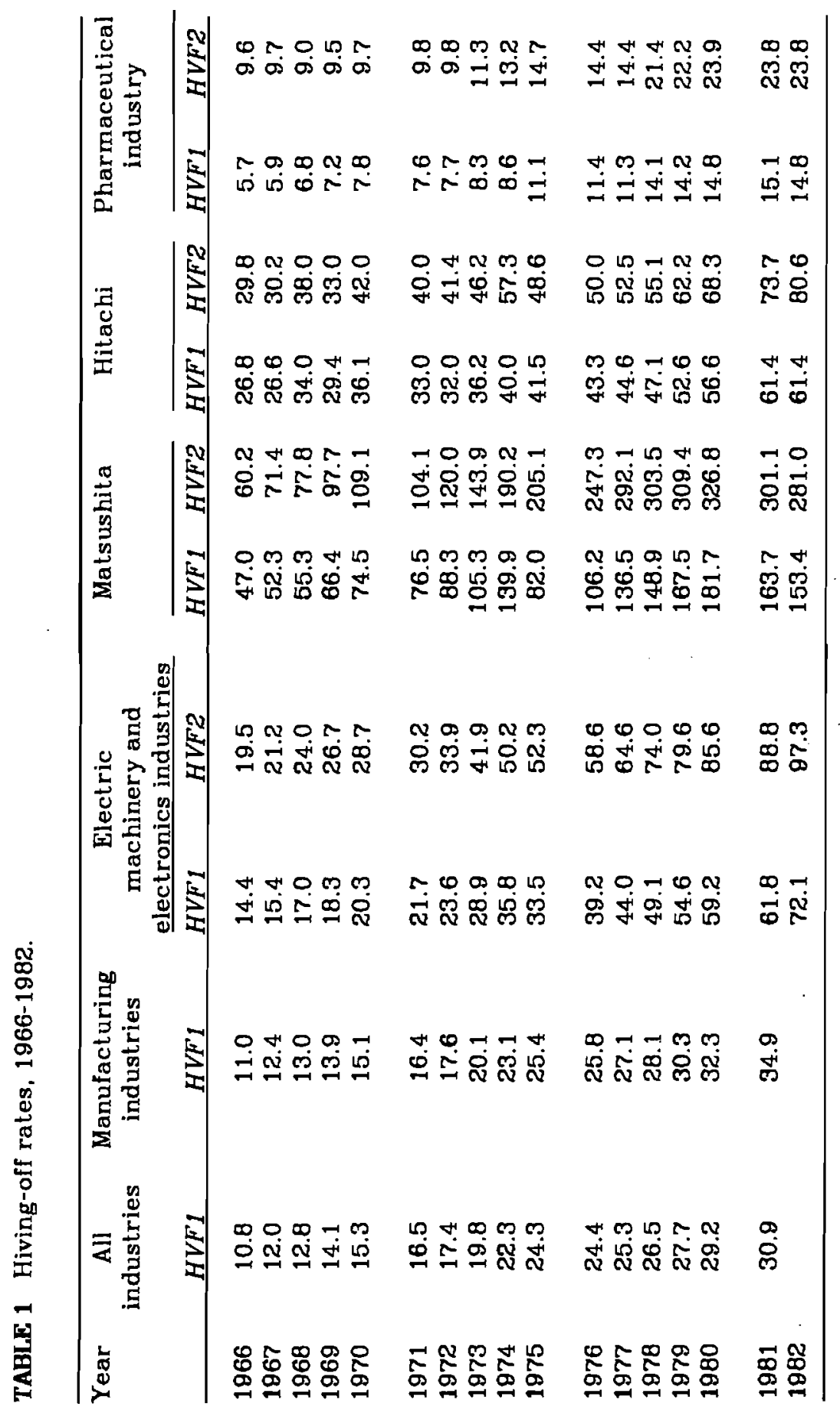


to a certain degree), aggregated HVFZ values exaggerate the extent of the control exercised by the listed firms concerned, but HVFZs for individual large firms such as Matsushita and Hitachi, where no more than $20 \%$ of the stock is owned by any single holder, may give a more precise picture as regards the extent of control exercised by these firms over other smaller firms. Table 1 was constructed from annual financial statements of the listed firms, and investments in subsidiaries and related firms are given in terms of book values, which are normally equivalent to acquisition values unless adjusted for possible capital losses.

The table shows an impressive increase in the extent of investment in both subsidiaries and related firms by large Japanese firms over the last two decades. In one of the fastest-growing and most high-technology-oriented industries -- the electric machinery and electronics industry (referred to hereafter as the EE industry) - which we will examine particularly closely in this paper, almost three-quarters of the total paid-in capital values of all listed firms are reinvested in subsidiaries.

Tables 2 and 3 summarize the results of pooling annual time-series data on HVF1 and HVFZ for all listed firms in the EE industry over the period 19661982 and running linear regressions on the logarithm of various indexes of firm size and time variables, where:

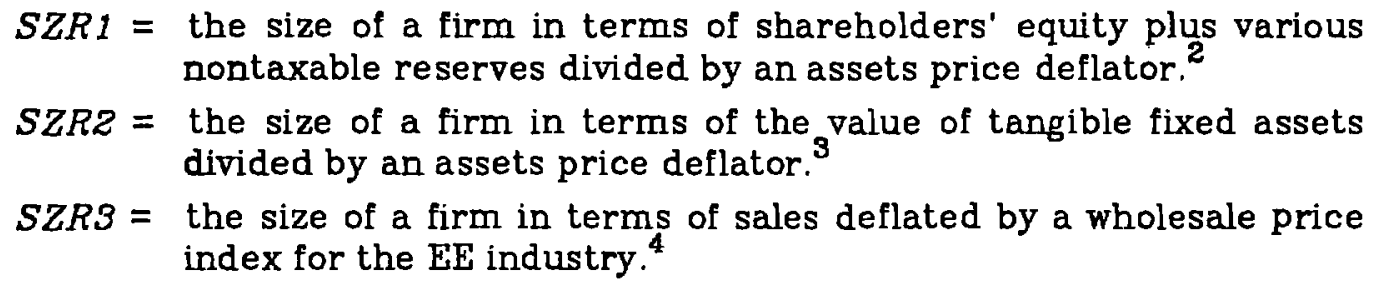

The regression coefficients are highly significant. For a given firm size, HVF1 increases at between $1.46 \%$ and $2.10 \%$ per annum. There is a clear tendency toward increased hiving off over the period. Also, a 10\% annual increase in various size indexes alone would contribute an additional increase of $1.0-1.1 \%$ in HVF1 and 1.4-1.6\% increase in HVF2. This may indicate that when a firm increases its size in terms of its assets or sales, it tries to preserve its flexibility and minimize various diseconomies of scale through hiving off some of its activities by establishing subsidiaries.

This propensity may be also inferred from the results (shown in Table 3) of employment regressions conducted by pooling time-series data for all listed firms in the EE industry over the period 1966-1982, where:

$L E S R=$ the logarithm of the number of employees per unit sales deflated by the industry wholesale price index.

$I N V=$ the value of inventory per unit sales deflated by the industry wholesale price index.

The regressions suggest that a fair degree of economies of scale and a substantial amount (around 10\% per annum) of technological improvement in labor saving have been achieved. But controlling these two factors one finds that the estimated elasticity of employment intensity with respect to $H V F 1$ is significantly negative. A $10 \%$ increase in HVF1 is expected to decrease the employment intensity by $0.93-1.56 \%$, depending upon the size index used. 
TABLE 2 Hiving off regressions, electric machinery and electronics industry.

\begin{tabular}{lllllll}
\hline & \multicolumn{3}{c}{$H V F 1$} & & \multicolumn{3}{c}{ HVFZ } \\
\hline CONSTANT & -15.6 & -14.9 & -24.6 & -19.2 & -18.5 & -32.5 \\
& $(-6.21)$ & $(-6.02)$ & $(-9.02)$ & $(-7.12)$ & $(-6.88)$ & $(-11.1)$ \\
LSZR1 & 10.3 & & & 14.1 & & \\
LSZRZ & $(15.7)$ & & & $(20.1)$ & & \\
LSZR3 & & 10.7 & & & 14.8 & \\
& & $(16.4)$ & & & $(21.2)$ & \\
$T(1966=1)$ & 2.01 & 2.10 & 1.46 & 2.39 & 2.51 & 1.58 \\
& $(9.29)$ & $(9.89)$ & $(6.43)$ & $(10.3)$ & $(11.1)$ & $(6.53)$ \\
\hline ADJ.R*R & 0.153 & 0.158 & 0.144 & 0.213 & 0.224 & 0.209 \\
$F-V A L$ & 207.6 & 217.4 & 196 & 312.3 & 335.9 & 308.8 \\
$N$ & 2308 & 2328 & 2328 & 2308 & 2328 & 2328 \\
\hline
\end{tabular}

Figures in parentheses are $t$-values.

TABLE 3 Employment regressions, electric machinery and electronics industry.

\begin{tabular}{lllllll}
\hline \multicolumn{7}{c}{ LESR } \\
\hline CONSTANT & 3.454 & 2.368 & 3.438 & 2.338 & 3.586 & 2.539 \\
& $(163.7)$ & $(49.2)$ & $(162.3)$ & $(48.3)$ & $(159.9)$ & $(52.9)$ \\
HVF $1 \times 10^{-2}$ & -0.148 & -0.101 & -0.156 & -0.106 & -0.131 & -0.093 \\
& $(-8.54)$ & $(-6.50)$ & $(-8.89)$ & $(-6.71)$ & $(-7.83)$ & $(-6.12)$ \\
LSZR1 & -0.089 & -0.089 & & & & \\
LSZRZ & $(-15.4)$ & $(-6.5)$ & & & & \\
LSZR3 & & & -0.078 & -0.082 & & \\
TINE & & & $(13.3)$ & $(-15.6)$ & & \\
& & & & & -0.125 & -0.117 \\
INV & $(-57.3)$ & $(-60.2)$ & $(-58.0)$ & $(-60.9)$ & $(-53.2)$ & $(-56.1)$ \\
& & 0.357 & & 0.362 & & 0.340 \\
\hline ADJ.R*R & 0.672 & 0.740 & 0.664 & 0.733 & 0.692 & 0.753 \\
$F-V A L$ & 1573.2 & 1637.8 & 1527.6 & 1597.3 & 1739.8 & 1772.1 \\
$N$ & 2308 & 2308 & 2328 & 2328 & 2328 & 2328 \\
\hline
\end{tabular}

Figures in parentheses are $t$-values. 
If we include the $I N V$ variable in the regression equations, the $t$-statistics of $H V F$ coefficients deteriorate, although the fits are improved in terms of adjusted $R * R$. The coefficients of $I N V$ are significantly positive. This may indicate that, when the $X$-efficiency of a firm declines through an accumulation of inventory relative to the size of sales, the firm tends to retain more employees as well. This is presumably due to the relative security of jobs in the short term with large Japanese firms, and the accumulation of inventory relative to sales is likely to be accompanied by redundant employment.

\section{CENTRALIZED OR DECENTRALIZED R\&D?}

Having established that large Japanese firms hive off a great deal of their activities to subsidiaries, the next interesting questions may be posed as follows. Do large firms hive off only routine production activities while retaining strategic activities, including $R \& D$, in their own hands? Do parent firms specialize in "brain" activities while their subsidiaries perform only "mechanical" functions? More specifically, are R\&D activities centralized in parent firms? I have attempted some regression analysis regarding $R \& D$, but data for the $E E$ industry turned out to be quite deficient, since many firms including the two giants, Matsushita and Hitachi, do not report $R \& D$ expenditures in their annual reports. I adopted the simple classical expedient for coping with missing data by dropping all observations that lacked information on $R \& D$ expenditure. which reduced the sample size drastically. In order to compensate for this, I tried additional regression for the pharmaceutical industry (hereafter referred to as the $P$ industry), which is, together with the EE industry and the chemical and transportation-machinery industries, among the most R\&D-intensive sectors and which has complete data at least for the period from 1972 onward. The regression results are summarized in Table 4, where:

$L R D R=$ the logarithm of $R \& D$ expenditure of a firm deflated by the industrial wholesale price index.

$E N T=$ the entropy measure in terms of sales shares of all listed firms in the industry concerned in the previous year.

For those firms in the EE industry reporting R\&D expenditures, the coefficients of $H V F$ are significantly negative, which implies that when these firms hive off subsidiaries, they also hive off $R \& D$ activities as well, to at least some extent. On the other hand, the regression coefficients for the firms in the $P$ industry are not significantly different from zero.

In connection with the Schumpeterian hypothesis, one noteworthy result is that the elasticities of $R \& D$ expenditures with respect to size are significantly greater than one, indicating that larger firms are relatively more active in inventive activities, ${ }^{5}$ other factors being equal. But note that our model is recursive and that relatively larger firms tend to hive off $R \& D$ activities, so that a certain amount of the observed reduction in $R \& D$ effort probably arises from this indirect path.

The ENT variable is added here to examine the effects of market uncertainty and the degree of concentration of the industry concerned. As the entropy variable has a high correlation with the time variable $(0.954$ in the EE industry and 0.909 in the $P$ industry) indicating increasing competitiveness and uncertainty of the markets over the period studied, the reliability of regression coefficients are not high, so that we are unable to confirm the Schumpeterian hypothesis that a higher degree of concentration of the market is more conducive to $R \& D$ efforts. 
TABLE 4 R\&D Regressions.

\begin{tabular}{llllllllll}
\hline & \multicolumn{4}{c}{$\begin{array}{c}\text { (Electric machinery } \\
\text { and electronics industry) }\end{array}$} & \multicolumn{5}{c}{ (Pharmaceutical industry) } \\
\hline CONSTANT & -3.388 & -3.023 & -5.062 & -2.172 & -4.873 & -3.677 & -4.798 & -5.820 \\
& $(-28.1)$ & $(-26.2)$ & $(-39.2)$ & $(-0.450)$ & $(-47.5)$ & $(-0.789)$ & $(-46.01)$ & $(-49.6)$ \\
HVF $1 \times 10^{-2}$ & -0.632 & -1.191 & -0.726 & -0.723 & -0.013 & -0.013 & -0.009 & -0.085 \\
& $(-5.50)$ & $(-10.21)$ & $(-7.06)$ & $(-7.03)$ & $(-0.228)$ & $(-0.229)$ & $(-0.125)$ & $(-1.009)$ \\
LSZR1 & 1.256 & & & & 1.109 & 1.108 & & \\
& $(36.2)$ & & & & $(43.8)$ & $(43.8)$ & & \\
LSZR2 & & 1.404 & & & & & 1.095 & \\
& & $(36.7)$ & & & & & & \\
LSZR3 & & & 1.497 & 1.496 & & & & 1.169 \\
& & & $(41.9)$ & $(41.9)$ & & & & \\
TIME & 0.036 & 0.045 & 0.043 & 0.060 & 0.068 & 0.073 & 0.082 & 0.065 \\
& $(4.18)$ & $(5.29)$ & $(5.67)$ & $(2.40)$ & $(8.78)$ & $(3.85)$ & $(10.3)$ & $(6.66)$ \\
$E N T$ & & & & -1.239 & & -0.343 & & \\
& & & & $(-0.712)$ & & $(-0.257)$ & & \\
\hline ADJ.R *R & 0.754 & 0.754 & 0.804 & 0.805 & 0.638 & 0.638 & 0.623 & 0.617 \\
$F-V A L$ & 478.6 & 477.4 & 639.6 & 479.3 & 747.5 & 560.2 & 708 & 687.3 \\
$N$ & 468 & 468 & 468 & 468 & 1275 & 1275 & 1286 & 1286 \\
\hline
\end{tabular}

\section{REIATIONS OF SUBCONTRACTORS WITH PARENT FIRMS}

As noted already, Japanese firms, in addition to hiving off subsidiaries, also avoid the inflexibility associated with large size through the ever-increasing development of vertical links with smaller firms from which they subcontract work or to which they supply other services. There are no statistical data to show directly the increase in subcontracting from the side of larger parent firms (subcontractees), but a good official survey of small and medium-sized firms is conducted by the Ministry of International Trade and Industry (MITI) every five years. According to this Basic Survey on the Industrial Situation (Kogyo Jittai Chosa, hereafter referred to as the IS Survey) the proportion of small and medium-sized firms in all manufacturing industries with less than three hundred employees that are engaged in subcontracting increased from $53.3 \%$ in 1966 to $65.5 \%$ in 1981 . The proportion in the $\mathrm{EE}$ industry in 1981 was $85.3 \%$ - among the highest overall.

The so-called "dual structure" hypothesis, which has become somewhat outmoded in Japan in its original, straightforward form, but which still seems to be prevalent elsewhere, suggests that larger firms utilize and exploit smaller subcontractors as shock absorbers, thus causing the brunt of business-cycle adjustments to fall on the smaller firms through semifeudalistic exercises of power. It was held in the 1950 s and early 1960 s that this semifeudalistic institution should, and would, disappear and give way to a new egalitarian and freely competitive industrial organization as the economic modernization of Japan progressed. However, despite this prescription-cum-prediction, more and more small and medium-sized firms have increasingly entered into 
subcontracting relations with larger firms. Is the Japanese economy tending toward a reversal of the modernization of industrial structure, thus strengthening the hierarchical control by larger firms?

In order to consider this problem, let me point out three newly emerging aspects of subcontracting relations. First, the relation of subcontractors with parent firms is not normally exclusive. According to the IS Survey, the average number of parent firms with which small and medium-sized firms have subcontracting relations, over all manufacturing industries, is four (three in the $\mathrm{EE}$ industry). This number increases as the size of the subcontractor increases. The average number of parent companies of medium-sized firms (with less than 300 but more than 200 employees) is eleven (ten in the EE industry). The possibility of multiple relations can enhance the bargaining power of subcontractors when they deal with parent firms, as compared with the situation in which they lack such outside opportunities. This tendency for overlapping relations is also confirmed by another authoritative survey conducted by Shoko Chukin Bank (hereafter referred to as the SCB Survey). This survey found that of 1952 subcontractors surveyed, $56.7 \%$ wanted to increase the number of parent firms while only $1.5 \%$ of them wished to decrease it. This desire for more extensive multiple relations is particularly strong among the relatively small firms, while relatively larger firms with more than 300 employees aspire to reduce their dependence on subcontracting and orient themselves toward more autonomous positions.

Secondly, subcontracting relations are not primarily used as a business fluctuation buffer, but increasingly for the technological expertise and managerial abilities that the subcontractors have come to accumulate. Another recent survey conducted by the Agency for Small and Medium Enterprises (A Survey on the Subcontracting Situation 1982, Shitauke Kigyo Jittai Chosa, hereafter referred to as the SS Survey) reports that the proportions of both subcontractors and parent firms that regard the buffer function as a primary factor behind the spread of subcontracting was less than $10 \%$ of all firms surveyed. On the other hand, the reliability of product quality and the specific knowhow possessed by the subcontractors, etc., are regarded as increasingly important factors by the parent firms (SS Survey 1982).

Thirdly, the absorption of shocks exclusively by subcontractors does not seem to be as widespread as it used to be; various types of risk-sharing between parent firms and subcontractors seem to have become more prevalent. It has been noted already that, according to the SS Survey, the buffer function is not regarded as important either by parent firms or by subcontractors. Instead, about one-third of the parent firms surveyed considered that subcontracting reduces the cost of production, while about three-quarters of the subcontractors regarded "reliable long-term relations" as a primary factor when entering into subcontracting arrangements. This indicates that, contrary to the stereotyped dual structure hypothesis, parent firms rather act as "insurers" for relatively smaller subcontractors in exchange for "insurance premiums" in the form of semimonopsonic gains. I will show later that this supposition does indeed conform with collective economic rationality.

\section{TREE AND QUASI-TREE STRUCTURE}

The industrial organizational picture emerging from the above description is considerably different from that depicted by the dual structure hypothesis. The generalized dual structure hypothesis, combined with the stereotyped view of the role of government, as represented by the "Japan, Inc." theory, may be visualized as the "tree" structure shown in Figure 1. At the apex is the Ministry 
of International Trade and Industry (MITI), which controls and directly supervises a few representative giant firms. The latter, in turn, exclusively control smaller subsidiaries and subcontractors, which have further relations with still smaller firms from which they re-subcontract, etc., and so on. The large controlling firms form their own, mutually-exclusive corporate groups.

As an alternative to this traditional view, we now visualize an emerging aspect of the industrial structure in terms of the "quasi-tree" structure shown in Figure 2. The structure of the tree is only "quasi" in the following three senses. First, the role of government is not one of unidirectional control, but rather one of an information exchanger and mediator for any cooperative venture as the need arises. The government mediates among large firms as well as small and medium-sized firms. If we confine our attention to the sphere of $R \& D$, the role of the government as a source of $R \& D$ funds is not overwhelming in Japan. As Table 5 shows, Japan ranks lowest among most technologicallyadvanced and R\&D-oriented nations in this respect: a major portion of $R \& D$ research funds originates in private industry. In forming and operating the much-publicized Cooperative Research Labs for Very Large Scale Integrated Circuits in the 1970s, the government share in terms of funds contributed was limited. The essential role of MITI was to help organize two cooperative labs among six major competing computer manufacturers. Joint activities in manufacturing and marketing were avoided so as not to weaken the strong existing competition among the participating firms in the product market. Also, forming two labs rather than a single consolidated lab may be considered a good strategy, making the cooperative venture more robust with respect to the impact of possible mistakes. In practice, the Cooperative Labs were dissolved after a predetermined period.

Secondly, the structure generated by hiving off subsidiaries and utilizing subcontracting is "quasi-tree" in form since there are overlapping relationships between parent firms and smaller firms. In the rigid tree structure it is a little as though the members of a family (corporate group) cannot make friends (business partners) outside the family except when the family as a whole makes a friendship. It is structurally simple and neat. But the reality of the emerging structure is somewhat more messy. Industries are still loosely separated into several groups with large firms as their apexes, but there are now more overlaps. Smaller innovative firms are more willing to, and actually can, make contracts not only with their original parent firms but also with other firms outside the group. Also, the larger firms are themselves looking for more reliable and innovative subcontractors inside and outside their own groups, and want their subsidiaries to diversify business partners in order to secure efficient utilization of the subsidiaries' resources. There are generally more and more overlaps, and interconnections between firms are no longer necessarily solely through the medium of the groups they belong to. ${ }^{B}$

Another aspect of the emerging industrial organization that cannot be properly represented by the tree structure is that the direction of innovative initiative is not rigidly unidirectional from the trunk to major branches and then to minor branches. As already discussed, there is growing evidence that $R \& D$ activities in particular and innovative activities in general are becoming much more decentralized and dispersed from the top to the bottom. Small and medium-sized firms lacking their own technological expertise or readiness to innovate are losing their competitive edge in forming stable long-term relations with larger firms and may not even survive as viable members of corporate groups. On the other hand, even the larger firms may lose their strategic position and yield their influential role in the group to their exsubsidiaries if they themselves fail to adapt to changing environmental 


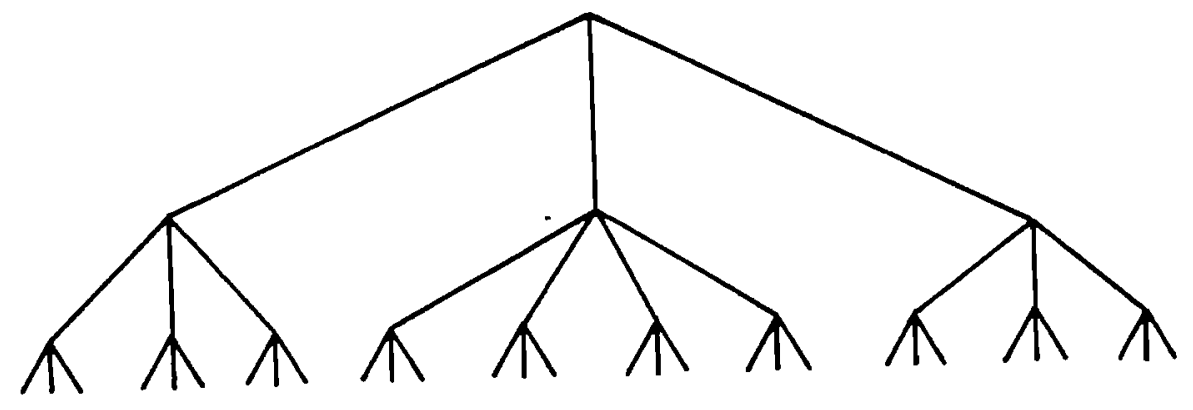

FIGURE 1 The tree structure.

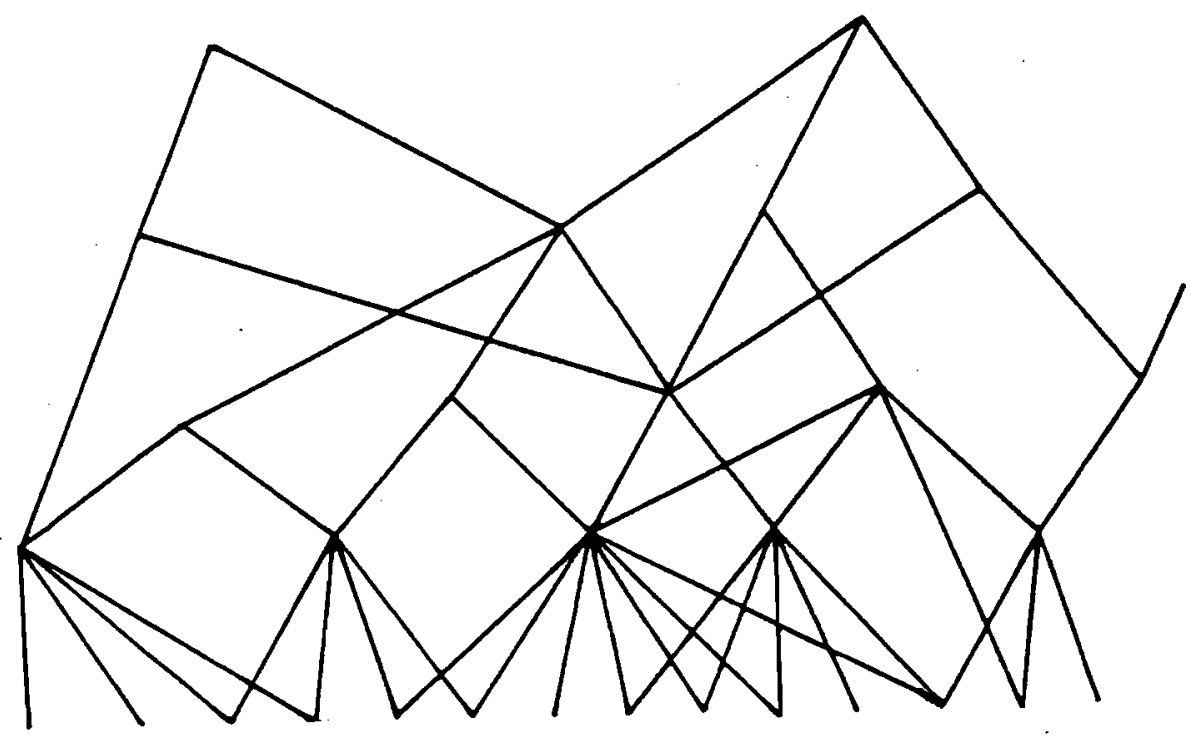

FIGURE 2 The quasi-tree structure. 
TABLE 5 R\&D Expenditure and government funds.

\begin{tabular}{lcccc}
\hline Country & Year & $\begin{array}{c}\text { R\&D Expenditure } \\
\text { (million8) }\end{array}$ & $\begin{array}{c}\text { Government funds } \\
(\%)\end{array}$ & $\begin{array}{c}\text { Government funds } \\
\text { excl. defense R\&D } \\
(\%)\end{array}$ \\
\hline Japan & 1979 & 18,546 & 27.4 & 26.9 \\
& 1980 & 20,651 & 25.8 & 25.4 \\
US & 1980 & 61,127 & 47.8 & 33.2 \\
UK & 1978 & 6,855 & 48.1 & 31.6 \\
FRG & 1979 & 17,369 & 46.8 & - \\
France & 1979 & 10,373 & 51.1 & 37.8 \\
USSR & 1980 & 32,269 & 46.7 & - \\
\hline
\end{tabular}

Sources: Japan: Agency for Science and Technology, Indicators of Science and Technology. US: National Science Foundation, National Patterns of Science and Technology Resources, 1981. UK, FRG, and France: OECD, International Statistical Year. USSR: Central Statistical Bureau, The Statistical Year Book of the National Economy.

conditions quickly, flexibly, and innovatively. Any decentralization and dispersion of control and innovative activities throughout the industrial organization is, needless to say, accompanied by a certain degree of dispersion of responsibility for the consequences, that is, the sharing of risks, and I will return to this point later.

\section{US/JAPANESE COMPARISONS}

The quasi-tree structure as described above contrasts strongly with that of the archetypal American industrial organization. The stylized pattern of American industrial organization may be characterized by monopolistic competition among a few dominant firms, within which the tree structure is internalized. When innovation-oriented managers and engineers spin out from large firms, they do so on their own initiative with the help of venture capital markets. If and when these hived-off firms become technologically and financially viable and successful, they are sometimes reabsorbed into larger firms through acquisition for the realization of capital gains. This type of dynamic behavior offers an interesting contrast to that generated under the Japanese system of industrial organization, characterized by quasi-disintegration of large firms on their own initiative and a certain degree of overlap between groups.

\section{QUASI-TREE VS. RIGID TREE STRUCTURES}

What are the relative advantages and disadvantages of the quasi-tree structure vis-d-vis the rigid-tree structure and the nonintegral atomistic structure from the theoretical point of view? I stress here "from the theoretical point of view," since we do not yet know whether these advantages, if any, have been fully realized in the emerging quasi-tree structure, so that any remarks are bound to be somewhat speculative. 
One possible advantage of the quasi-tree structure over integral centralization is that diverse innovative adaptation by the subunits to changing environments and evolutionary selection of appropriate dispositions may be relatively favored in the former. In large integrated firms, technological innovation is apt to be directed from the center on the single criterion of financial profitability. As stressed above, the long lines of communication within such firms may also fail to ensure the efficient use of decentralized knowledge available at lower levels and potentially useful for innovative adaptation. Of course, the potential merits of the quasi-tree structure may be counteracted by wasteful duplication of $R \& D$ efforts in multiple units within the structure and a lack of clear orientation of these efforts from the global point of view, but these disadvantages may be to some extent mitigated by the semi-direction received from larger parent firms. A more formal study of this issue of the relative efficiency of centralized pooling of knowledge versus decentralized use of knowledge is an important topic for future research.

Secondly, the quasi-tree structure may make monitoring of subunits more effective. Some quasi-market discipline has been deliberately introduced into large integrated firms by creating multidivisional profit centers, but this is essentially an accounting gimmick. In the quasi-tree structure, however, subunits are autonomous legal entities and are more openly susceptible to profit-making discipline. If a subunit makes a great mistake, it may become nonviable through bankruptcy!

Thirdly, the quasi-tree structure, in which subunits are semi-autonomous entities, may make the management of industrial relations more flexible and adaptable to diverse conditions. There has been a worldwide tendency toward corporate- or plant-level bargaining since the beginning of the 1970 s as opposed to industry- or region-specific bargaining. This is a natural consequence of the growing importance of firm-specific employment structures as opposed to "invisible-hand" allocation. Particularly in Japan, the tendency toward corporate-level bargaining has been firmly institutionalized in the form of enterprise unionism, involving white-collar as well as blue-collar workers. In this situation, if the size of firms is too large, the union leadership may find it difficult to represent and satisfactorily aggregate the diverse interests of its various constituents. In some cases the maintenance of enterprise-based unionism that has no formal legal foundation could become difficult, leading to possible union rivalries within single firms. I suggest that one of the strongest motives for the quasi-disintegration of large Japanese firms is the need for the decentralization and localization of human resources management (see the Introduction to Aoki (19B4a) for details).

This view is, of course, somewhat akin to our old friend, the dual structure hypothesis, which claims that the benefits of job security through life-time employment, wage premiums, etc., are only available to privileged employees of larger firms and that employees of subcontractors must bear the brunt of business cycles in the form of insecure jobs, overtime working, lower wages, etc. It is true that there is some differentiation in wages and other conditions of employment between larger and smaller firms. But it must also be remembered that when subsidiaries and subcontractors have accumulated their own technical knowhow and expertise, embodied in human resources, job security tends to be extended to these employees as well (Koike 1984). On the other hand, if labor requirements decrease at a larger firm then adjustments are also made: first in the form of work-sharing, then in transfers of employees to related firms, and in extreme cases lay-offs or the strongly encouraged early retirement of senior employees, which are effectively discharges in all but name. This suggests that the bearing of business-rycle risks is never strictly 
unilateral, but is rather shared between employees of larger and smaller firms, albeit to different degrees.

One foreseeable problem is, however, the following. As innovative competition among smaller firms becomes keener through the increasing impact of "mechatronization" and other high technology, firms that are defeated in the competition may cease to be viable units in the quasi-tree structure. Further, through the introduction of mechatronics and robots, the advantage of hiving off human resource management may decrease, and larger firms may be induced to reinternalize some of the hived-off activities. Then the problem of unemployment or disguised unemployment outside the quasi-tree structure may become apparent, and a dual structure may reemerge in a new form.

Some observers argue that the impact of mechatronics on employment will be minimal in Japan because of its less-rigid job demarcations, and the prevalence of flexible job transfers within firms. But this view, although it may be valid to a certain limited extent, seems to me a little myopic and superficial.

\section{RISK SHARING IN THE QUAST-TREE STRUCTURE}

The relative advantages of the quasi-tree structure so far discussed, such as the diversity of innovative adaptation, effective monitoring through profit discipline, and decentralized industrial relations congruent with the formal structure of employment of firms, may also be said to be available in the atomistic structure of the economists' favorite parable, in which small firms compete with and relate to each other through perfect competition. But one of the most important aspects of the quasi-tree structure, which distinguishes it from the invisible-hand mechanism, is the possibility of sharing long-term risks among a number of firms.

If there is a vertically-related corporate group of many firms indexed by $i=1,2, \ldots, n$, facing external uncertainty as a whole and each having a different degree of constant absolute risk aversion $A(i)$, then efficient risk sharing is realized when the group minimizes the collective risk cost defined by $\sum A(i) \sigma^{2}(i)$, where $\sigma^{2}(i)$ denotes the ex ante variance of the $i$ th firm's revenue (see Aoki (1984b) for details). Then, it is clearly more efficient to attribute more risk (larger variance) to the (relatively) more risk-taking firms. If one firm, $j$, is risk neutral so that $A(j)=0$, then it is most efficient for the group to let firm $j$ bear all the risk involved and to assure other firms constant revenues. The benefits to the group made possible by efficient risk-sharing in terms of the reduction of collective risk cost may be distributed among the member firms according to their relative bargaining power. Relatively larger shares are most likely to go to the (relatively) more risk-taking firms. In other words, risk-taking firms assume higher risks in exchange for higher benefits accrued as risk premiums.

Now, in the quasi-tree structure larger firms at the apex are normally more diversified in their products and financially more viable. Therefore, they may be able to assume more risk by pooling and spreading risks, in contrast to smaller firms, which are likely to be more specialized in products and more limited in terms of financial resources. Therefore it seems more efficient for the quasi-tree structure that relatively larger firms assume relatively larger risks in exchange for insurance premiums in the form of monopsonic/monopolistic gains. I have already suggested that Japanese corporate groups seem to approximate such arrangements. 
The long-term ex ante risk-sharing arrangement is not, however, in general efficient ex post, as the short-term efficient marginal condition is not necessarily approximated in the long-term setting. There may be an incentive, therefore, for some member firms to default on such long-term arrangements $e x$ post unless there is an effective enforcement mechanism. In the rigid-tree structure, in which corporate control is extended over subsidiaries and monopsonic (monopolistic) control is exercised over subcontractors by parent firms, the default on ex ante arrangements may not be so problematic, at least from the side of the smaller firms. But, as overlapping of corporate groupings becomes more prevalent and interfirm relations become more fluid, the maintenance of long-term risk-sharing arrangements that do not in general satisfy ex post profit-maximizing conditions may become equivocal. In these circumstances the realization of efficient risk-shifting may also become problematic, unless relatively smaller firms become more risk-taking through increasing diversification and resource accumulation.

\section{CONCLUSIONS}

In this paper I have focused on the hiving-off tendency of large Japanese firms and examined its implications for the workings of the industrial organization. By examining the increasing overlaps between corporate groupings, I deduce a stylized model of industrial organization, which I refer to as the quasi-tree structure. I have hinted at a few of the factors, such as diverse innovative efforts, effective monitoring, localization of industrial relations, and efficient risk-sharing, operating within this structure. These factors may make the system more adaptable and flexible with respect to external uncertainties, which is a performance characteristic that has been recognized as increasingly important since the beginning of the 1970s. One could say that, if entrepreneurship is now identified with flexible and innovative adaptation to external uncertainties (shocks), then entrepreneurship is now beginning to be dispersed throughout the quasi-tree structure rather than concentrated in large firms as Schumpeter anticipated.

The quasi-tree structure is just one emerging aspect of japanese industrial organization: its future is as yet unknown and its workings are not yet fully understood. But since economists have hitherto devoted exclusive attention to the dichotomy of centralization vs. decentralization, and since the stereotyped view regarding the Japanese industrial organization as a rigid hierarchical dual structure is still prevalent, this attempt to identify and formalize a new mechanism may be warranted. Nevertheless, much work remains to be done on the performance characteristics of the quasi-tree structure as compared to the mechanisms of pure centralization and pure decentralization.

\section{ACKNOWLFDGMENTS}

The regression results reported in this paper were skillfully obtained by Mr. Hajime Kobayashi, of the Econometric Section, Data Bank Bureau, Nihon Keizai Shimbun. 


\section{NOTES}

1. See Schumpeter (1934, p.61). This expression is an addition to the English Edition.

2. The shareholders' equity may not be a good index for measuring the size of a firm, for there is normally a substantial amount of off-balance sheet assets due to the lack of inflation accounting. Particularly, the underestimation of land value is usually nonnegligible. But I suggest that the shareholders' equity (the net assets) plus nontaxable reserves is a better index than the total assets for a variety of reasons, as I explain in detail in the introduction to Aoki (1984a). The reserves include the reserve for Employees' Retirement Compensation; for this too, see Aoki (1984a). Specifically, $S Z 1$ is the sum of the items (66). (69), and (78) of the NEEDS Corporate Financial Data divided by the asset deflator given in the National Accounts of the Economic Planning Agency $(1975=100)$. This deflator is available only for the period 1969-1982; for the period 1966-1968 we constructed it by extrapolation.

3. Item (20) of the NEEDS Corporate Financial Data divided by the equipment stock deflator for the nonfinancial corporate sector, PIOP75 $(1975=100)$, given by NEEDS.

4. As a wholesale price index for the EE industry, we used WPI80G0124 given by NEEDS.

5. This result differs from what has been discovered for US firms; see Scherer (1967) and Kamien and Schwartz (1975). As is shown by Fisher and Temin (1973), the fact that the elasticity of R\&D expenditures with respect to the size of a firm exceeds one does not itself confirm the Schumpeterian hypothesis without additional assumptions concerning the technology of inventive activities.

6. As an example, Nippon Denso Co. Ltd., was first set up as a subsidiary of Toyota Motor Corporation, and, at the end of 1979, 22.0\% of its stock was still held by the latter while $8.6 \%$ was held by Toyota Automatic Loom Co. an original parent corporation of Toyota Motor Co. But Nippon Denso now supplies important car electronics equipment not only to Toyota Corporation but also to other rival firms.

\section{REFFRENCES}

Aoki, M. (1982). Equilibrium Growth of the Hierarchical Firm: ShareholderEmployee Cooperative Game Approach. American Economic Review, 72:1097-1110.

Aoki, M. (Ed.) (1984a). The Economic Analysis of the Japanese Firm. NorthHolland, Amsterdam, fortheoming.

Aoki, M. (1984b). Risk-sharing in the Corporate Group. In M. Aoki (Ed.), The Econamic Analysis of the Japanese Firm. North-Holland, Amsterdam, forthcoming.

Fisher, F.M. and Temin, P. (1973). Returns to Scale in Research and Development: What Does the Schumpeterian Hypothesis Imply? Journal of Political Economy, 81:56-70.

Geroski, P.A. and Jacquemin, A. (19B3). Large Firms in the European Corporate Economy and Industrial Policy in the 1980s. Working Paper 
No.8301. Institut des Sciences Economiques, Universite Catholique de Louvain.

Hayek, F. (1945). The Use of Knowledge in Society. American Economic Review, 35:519-530.

IS Survey (1981). Report of the Basis Survey on the Industrial Situation. Ministry of International Trade and Industry, Tokyo.

Kamien, M.I. and Schwartz, N.L. (1975). Market Structure and Innovation: A Survey. Journal of Economic Literature, 13:1-37.

Klein, B. (1979). The Slowdown in Productivity Advances: A Dynamic Explanation. In C.T. Hill and J.M. Utterback (Eds.) Technological Innovation for a Dynamic Economy. Pergamon Press, Oxford.

Koike, K. (1984). Skill Formation on the Shop Floor: Japan and the US. In M. Aoki (Ed.). The Economic Analysis of the Japanese Firm. North-Holland, Amsterdam, forthcoming.

Raiffa, H. (1982). The Science and Art of Negotiation. Harvard University Press, Cambridge, Massachusetts.

SCB Survey (1983). Shitauke Chusho Kigyo no Shin Tenkai. Ṡhoko Chukin Bank, Tokyo.

Scherer, F.M. (1967). Firm Size, Market Structure, Opportunity, and the Output of Patented Inventions. American Economic Review, 57:1097-1125.

Schumpeter, J. (1934). The Theory of Economic Development. English translation by R. Opie. Harvard University Press, Cambridge, Massachusetts.

SS Survey (1982). The Survey on the Subcontracting Situation. Ministry of International Trade and Industry, Tokyo. 